\title{
CXCL5 wt Allele
}

National Cancer Institute

\section{Source}

National Cancer Institute. CXCL5 wt Allele. NCI Thesaurus. Code C49766.

Human CXCL5 wild-type allele is located within $4 q 12-q 13$ and is approximately $3 \mathrm{~kb}$ in length. This allele, which encodes C-X-C motif chemokine 5 protein, plays a role in the stimulation and chemotaxis of neutrophils, monocytes, lymphocytes, and fibroblasts. 